\title{
DEVELOPMENT OF A SYSTEM OF INTERNATIONAL SCIENTIFIC RESEARCH COOPERATION IN RUSSIA
}

\author{
Veronica U. Chernova \\ Faculty of Economics \\ Peoples' Friendship University of Russia \\ (RUDN University) \\ Moscow, Russia \\ veronika_urievna@mail.ru
}

\author{
Ekaterina Andreevna Degtereva \\ Faculty of Economics \\ Peoples' Friendship University of Russia \\ (RUDN University) \\ Moscow, Russia \\ degseb@mail.ru
}

\author{
Sergey U. Chernikov \\ Faculty of Economics \\ Peoples' Friendship University of Russia \\ (RUDN University) \\ Moscow, Russia \\ chernikov.rudn@gmail.com
}

\begin{abstract}
In the modern world the problems of science, education and industry integration have proved to be central to major academic and political dispute. These issues are highly relevant for Russia in its present state of development. However, it seems that the lack of sufficient investment in $R \& D$ is becoming the fundamental factor of poor progress in innovation development. In this paper the authors elaborate that the formation of the international research cooperation structure for the purposes of Russian Federation should be accompanied by a more steady integration into the global technological system through wide cooperation networks.
\end{abstract}

Keywords - innovations, economic growth, globalization, integration, research projects

\section{INTRODUCTION}

In modern conditions1, any state should pay special attention to the intensive development of research. Today we can observe a new stage of postindustrial development, where the success depends on the joint efforts of $R \& D$ actors. According to many scientists, innovation is a factor of qualitatively new economic growth that allows providing high competitive advantages, improving the efficiency and effectiveness of any process (T.A. Shaklein, A.N. Panov, A.S. Bulatov, 2017; L. A. Tolstolesova, 2013; T. G. Ozernikova, 2015)

There is a widespread view that the joint research cooperation can bring the most tangible effects on economic and social development (Meloyan, V.G., Shevchenko, 2017; Temirbekova, A.B., Uskelenova, A.T., Boluspaev, Sh.A., Aldabergenov, N.A., 2015). Many countries are actively working to internationalize their science for a wide range of reasons. A growing number of states have developed a clear national strategy for research activities internationalization (for example, EU countries) (Guskova, N.D., Sushkova, Yu.N, 2015). These strategies commonly pursue two completely different sets of international scientific cooperation goals (Fedorov G.M, 2013; Enqing, Ch., 2012): "internal" goals directly aimed at substantiating research activities (large-scale construction of infrastructure, etc.) and "external" goals focused on supporting other areas of government regulation. Some of these goals, such as fighting climate change or space exploration, are collective in the sense that their outcomes cannot be efficiently shared between individual states or individuals. Therefore, their solution requires a joint universal approach, leading to a certain degree of duality and inconsistency of research party interests.

\section{THE INNOVATIVE POTENTIAL ANALYSIS}

The problem of science, education and industry integration is also relevant for Russia, which is in need of an active, purposeful cooperation with other countries both to strengthen its competitive position and to contribute to the solution of national problems posing a threat to the State economic security. The situation is compounded by the fact that longestablished contacts with the EU countries and the United States have nearly collapsed as a result of the sanctions imposed in relation to innovative projects in Russia, thus narrowing the possibilities of fruitful cooperation in the scientific field (Kuzmin, E.A., 2012; Chigirinskaya, N.V., 2014). 
In this regard, it is necessary to analyze the situation in the field of innovation, displayed through various global ranking indicators, characterizing the conditions of innovative development. The most widely known among the latter are World Bank's Doing Business index, the Global Innovation Index and the Global competitiveness Index of the Davos economic forum (Figure 1)

The analysis of the Russia's positions dynamics presented in Figure 1 demonstrates positive trends. The "Doing Business" rating analyzes two key aspects: National Business Initiative and the Index of Russian regions innovation development. Russia has advanced within this framework from 123rd place in 2011 to 51st in 2016. The "Doing Business" ranking is only indirectly related to innovation: it measures the success of government actions to provide a decent business environment for all types of companies. Nevertheless, a favorable environment is a basic prerequisite for innovative development. According to the "Global Innovation Index" rating, in six years Russia has improved its result from 64th to 43rd place, with approximately the same picture visible in the ranking of the "Global Competitiveness Index" (growth from 63rd to 43rd place). Researchers also point to the level of the general survivability increase among companies in Russia and steady growth of their stability in companies since 2000, but at the same time, the volatility increases their average life period (Guseva, V.E., Kuzmin, E.A., 2016; Kuzmin, E.A., 2018)

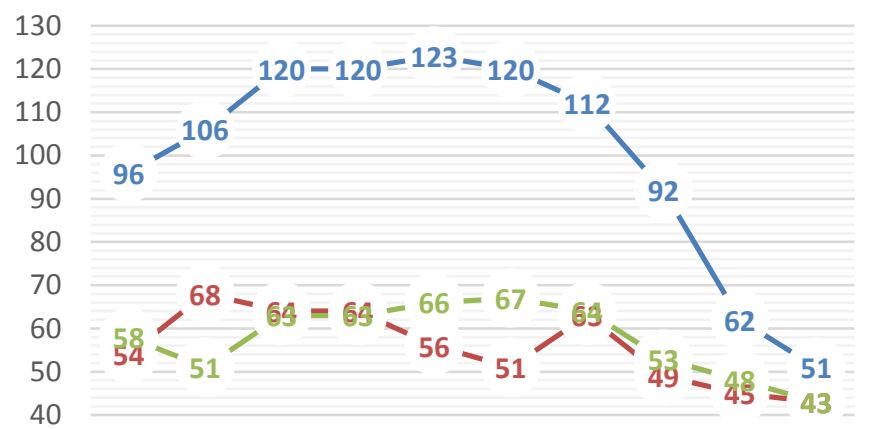

2007200820092010201120122013201420152016

$$
\begin{aligned}
& - \text { - Doing Business } \\
& - \text { - Global Innovation Index } \\
& - \text { - Global Competiveness Index }
\end{aligned}
$$

Fig. 1. Dynamics of Russia's positions in the innovative development ranking (synthesis according to Doing Business, Global Competitiveness Index, Global Innovation Index electronic resources).

However, upon deeper study of the components and related rating indicators that are responsible for the dynamics and degree of innovative development, the situation becomes somewhat less optimistic. Thus, in the "Global innovation index" ranking, most of the growth occurred in the "Innovative introductory sub-index" component, reflecting the country's investment in innovative development in the broadest sense, including efforts to create a favorable innovation environment. Due to investments to this component, the Russia rank rose in the last six years from the 82 to 44 position. Already in the second component (the "Sub-index of innovative products"),
Russia has only slightly improved its position, rising from $51 \mathrm{st}$ to 47 th place.

The "Global Competitiveness Index" divides countries into three groups depending on the main driving force of their economic development at this stage: countries with growth due to factors of production; countries growing due to the production efficiency rise; countries with growth due to incorporation of production innovations. In 2010 Russia was included in the second group of countries, and for the next seven years was not able to get into the first group.

Thus, assessing the efforts of the State to create conditions for the innovative way of development, the world ratings do not record a significant impact and point to the weakness of the innovation component of the economy as such. Judging from the dynamics of the ratings, Russia in recent years has not been able to make an "innovation leap" (figure 2).

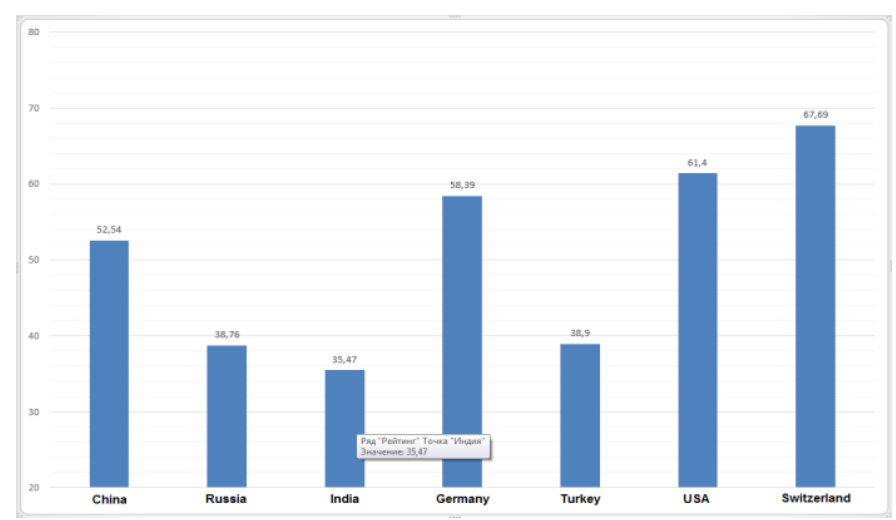

Fig. 2. Dynamics of Russia's Global Innovation Index (Data summarization from Global Innovation Index electronic resource)

An analysis of the data presented in figure 2 shows that the index value is significantly lower comparing to that in developed countries. Besides the systemic problems that limit Russia's capabilities in this area, the following factors should also be taken into consideration (Kuznetsov E.B., 2016): low number of foreign patents due to low level of national and international patent activity; lack of investment in R\&D; low share of high-tech and intellectual property exports; low efficiency of state governance; low labor productivity in nonprimary industries; problems in innovative and research clusters development.

It is assumed that the lack of sufficient investment in R\&D is the fundamental factor of poor progress in innovation development. An analysis organized by the Institute of Industrial Research, shows that global investment in R\&D in 2016 increased by $3.5 \%$ to a total of 1,948 trillion US dollars, with approx. 110 countries having significant share of such investments. As in previous years, the growth in global R \& D investment is largely driven by spending in Asian countries, particularly China. Table 1 shows the pattern of expenditures by region of the world. 
TABLE 1. GEOGRAPHICAL STRUCTURE OF R\&D EXPENDITURE BY REGION

\begin{tabular}{|c|r|r|r|}
\hline Region & \multicolumn{1}{|c|}{2014} & \multicolumn{1}{|c|}{2015} & \multicolumn{1}{c|}{2016} \\
\hline North America & $29,10 \%$ & $28,50 \%$ & $28,40 \%$ \\
\hline USA & $26,90 \%$ & $26,40 \%$ & $26,40 \%$ \\
\hline The Caribbean & $0,10 \%$ & $0,10 \%$ & $0,10 \%$ \\
\hline Asia & $40,20 \%$ & $41,20 \%$ & $41,80 \%$ \\
\hline China & $19,10 \%$ & $19,80 \%$ & $20,40 \%$ \\
\hline Europe & $21,50 \%$ & $21,30 \%$ & $21,00 \%$ \\
\hline Russia/CIS & $3,10 \%$ & $2,90 \%$ & $2,80 \%$ \\
\hline South America & $2,80 \%$ & $2,60 \%$ & $2,60 \%$ \\
\hline Middle East & $2,20 \%$ & $2,30 \%$ & $2,30 \%$ \\
\hline Africa & $1,00 \%$ & $1,10 \%$ & $1,10 \%$ \\
\hline
\end{tabular}

As we can see, the share of Asian countries (including China, Japan, India and South Korea) currently accounts for more than $40 \%$ of all global R\&D investments. The investments in North America account for less than $30 \%$, while European research and development - just a little more than $20 \%$. Russia and the CIS countries direct only $2.8 \%$ to research, and this figure decreases annually. Asian economies continue to grow faster than other parts of the world, and their investment in $\mathrm{R} \& \mathrm{D}$ is often several times higher than in the US and European countries (the rise is almost $1 \%$ per year, while the share of other regions of the world is declining).

International economic, technological and scientific competition is increasingly dependent on national investments in knowledge-intensive industries. Growing transnational science and technology networks among universities, research funding agencies and corporations are creating international competition. Assessing the current situation, it can be argued that there is a risk of further increase of the gap between $R \& D$ in Russia and its main global competitors, which in long term can lead to a serious lag impossible to overcome (Porokhovsky A.A, 2015). There is also the problem of continuing "brain drain", which is associated with the lack of demand for innovative solutions from Russian companies, primarily large ones. The actual demand for technology and innovation in Russia remains low, both in terms of business estimates and in terms of investments in intangible assets (figure 3 ).

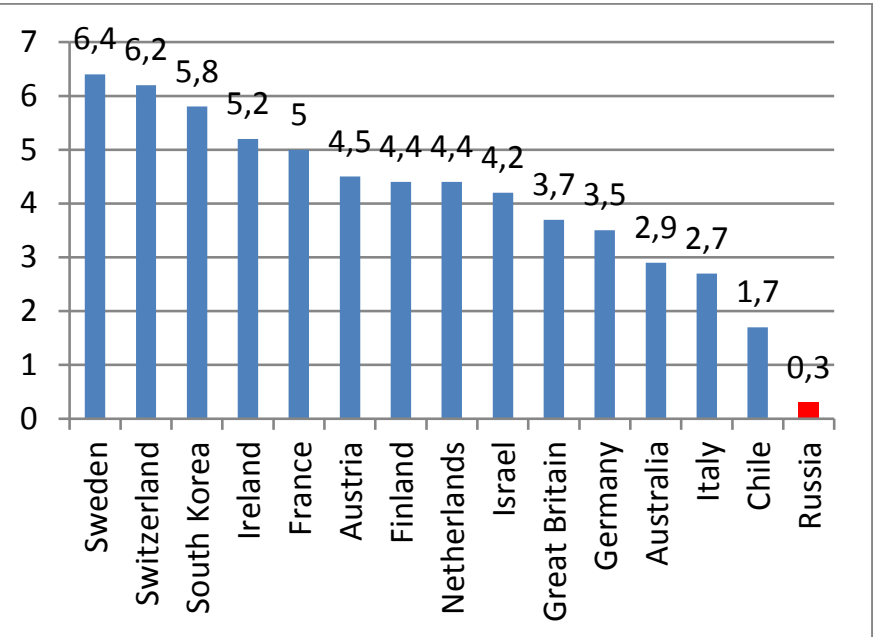

Fig. 3. Level of investments in intangible assets as percentage of GDP (Ozernikova, T.G., 2015)

As we can see, while the leading innovation activity countries dedicate over $5-6 \%$ to the matter, the rate of investment in intangible assets in Russia is only $0.3 \%$ of GDP, which indicates a low demand for technology. In the absence of domestic demand for new business solutions, Russian researchers and entrepreneurs are looking for buyers in foreign markets. Such intellectual migration has a certain specificity. Due to a feature of motivational attitudes - primarily the desire to realize their creative potential - persons with higher education level have a higher mobility rate. This leads to the top mobility being concentrated among the most valuable scientists with highest human capital, leading to decreased innovation potential. Also, such intellectual migrants rely more on networks based on relationships with colleagues and former classmates rather than on kinship and national connections (as in the case of less skilled migrants). As a result, these migration networks have a different quality, based mainly on education and professional links.

Such migration is also visible among the national entrepreneurs, aiming to build an advanced technology business. The problem is that currently high-tech business can be considered attractive and profitable only in case of having an early entry strategy to global markets, while focusing on domestic market is not seen as a realistic scenario for growth. However, the growth of startups in the absence of domestic demand for innovation does not lead to an increase in economic activity, but to the migration of technologies abroad, with subsequent re-imports of these technologies in the form of finished products. As a result, the Russian venture market, which is very competitive internationally in terms of investment, does not seem to correspond to the features and consumption power of the economy.

\section{PROSPECTS FOR THE RESEARCH COOPERATION DEVELOPMENT}

In these circumstances, the task of forming an effective system of research activities cooperation is becoming increasingly relevant for Russia. In addition to the abovementioned issue, today Russia faces a number of other tasks on the way to improving inter-country cooperation in the scientific 
field. First, Russia must revitalize the research and development system by reducing barriers to incoming talent mobility from other countries and between the public and private sectors.

In order to create a state-public system to involve researchers who once left in search of better conditions abroad in scientific and innovative activities in Russia, a system of well-thought-out measures is necessary. This is due not so much to the level of funds allocated for these events, but to the state of the Russian scientific community abroad and the difficulties of its cooperation with national colleagues back in Russia. Often problems arise due to the scientific backwardness of the latter in many areas and the lack of modern equipment. This is clearly a State level problem that can not be fully and hastily solved, therefore, it is necessary to use modern social connection technologies aimed at building and using social networks for the development of domestic science, education and innovative economy. Such networks already exist in the Western States and have proven their effectiveness. Surely, they need to be carefully revised in order to avoid their direct copying. This should take into account the mentality of Russian scientists and actively involve interested businesses. Generally, the world experience shows that the full return of previously emigrated scientists need significant financial State investments and the creation of new organizational structures. The "implantation" of returning scientists into traditional institutions causes a lot of problems, including sociopsychological ones. The "partial return" pattern, however, has much lower financial issues involved - for example, the allocation of funds for the creation of the laboratory, the salary of employees, the purchase of devices and reagents are usually much more more important for emigrated scientists and innovators than the wages, which they continue to receive abroad. Such programs exist in the world and have proven their applicability. As the cycle of scientific personnel reproduction is long-term, and the situation in Russian science does not give much hope for mass return of the emigrated innovators, such subsidized social networks have high potential. They would not only perform the functions of attracting the foreign Russian innovators to joint projects at home, but also greatly aid the monitoring of the realistic state of the Russian scientific output and its consolidation.

Secondly, there is a need to create a coherent policy of research and technology coordination with relevant countries. The international economic contacts of Russia currently cover many areas: international trade, foreign direct investment, technology transfer, licensing and patenting and many more. The main challenge for Russia is to find appropriate connections and balance between different types of flows and connect it to existing national $R \& D$ priorities. It seems that the current state of international scientific and technical cooperation is characterized by the intensive growth and expansion of the legal framework of bilateral and multilateral agreements in science and technology. This is accompanied with the implementation of large-scale programs to support research and launch joint research projects in a number of promising areas of research and development and foreign policy priorities of the Russian Federation. Along with a large number of bilateral intergovernmental agreements on scientific and technical cooperation with more than 40 countries, the newly emerged Ministry Science and Higher Education of Russia is focused on making interdepartmental agreements in science and technology. Recently a lot of documents regulating multilateral scientific and technological cooperation at the international level were presented through a number of multilateral agreements within the frameworks of BRICS, EU, CIS and other integration structures.

This outburst of diplomatic activities greatly increases the role of "scientific diplomacy" in the international scientific cooperation processes. The activities in this field are mostly intangible and can be brought down to the definition of "soft force". For example, these various proposals to introduce a public-state title "Ambassador of Russian science", or awarding of the annual public prize in the field of "scientific exchange and diplomacy" and organization a "Club of scientific diplomacy" with annual international meetings and seminars. However, in order to serve as a means to solving the abovementioned innovation development problems of Russia, these actions should be built into a long-term strategy of the development of scientific diplomacy and monitoring. Generally, it is common perception that developing countries should benefit from the transfer of technology and the experience of developed States. Studies show that such exchange even in the absence of strong links between partners are showing positive side effects in developed countries (Zobov A.M., Degtereva E.A., Chernova V.U., 2016). The same should work for developing countries, meaning the significant need to create conditions conducive to the formation of a national international research cooperation system (Yampolskaya, D.O., 2014; Vasiliev, A.V., 2014).

However, effective international cooperation of scientific organizations and the development of new forms of integration requires an innovative infrastructure, such as:

- Cooperation with foreign technology parks and technology transfer centers.

- Formation of an intellectual property center network as basis for joint research and educational projects.

- Implementation and organizational support of targeted government loans and loan guarantees, provision of tax credits for R\&D, including joint projects.

- Creating joint technical services and order collection points abroad for innovative companies.

- Creating international research centers and laboratories with highly qualified foreign specialists in Russia.

- Development of "soft competencies" (knowledge of foreign languages, intercultural communication skills, etc.) among employees of research institutes and universities to promote international relations.

- Introduction of research resource sharing patterns: equipment within unified laboratories, libraries, virtual networks, and databases with scientific information.

\section{CONCLUSION}

Summarizing the above-mentioned information, we can conclude that the formation of the international research 
cooperation structure should be accompanied by a more steady integration into the global technological system. Intensification of international cooperation is not only capable of expanding access to the missing knowledge and competencies in new technologies. It creates new jobs for researchers, encourages the dissemination of knowledge and experience, and serves as a basis for the development of long-term personal networks of collaboration between scientists and organizations. The new strategy needs to be focused on both establishing priorities among partner countries and defining specific areas of cooperation. Such priorities can be established only through differentiation between States on the basis of their competitive capabilities and the needs of society.

\section{Acknowledgement}

"The article was prepared as part of the project (unique identification number RFMEFI57217X0005) with the financial support of the Ministry of Science and Higher Education of the Russian Federation ".

\section{References}

[1] A.V. Vasiliev, "Peculiarities of the development of a multilevel system of higher professional education of Russia on the basis of integration into the international educational space", Vector of science TSU, vol. 1 (27), P. 206-209, 2014.

[2] T.A. Shaklein, A.N. Panov, A.S. Bulatov and others, "Foreign policy of Russia”, 1991-2016: [Collective monograph], Moscow, MGIMOUniversity, 2017.

[3] N.D. Guskova, Yu.N. Sushkova, "European Integration in the Context of European Studies: Realities and Prospects", Journal VUZov. The Volga region. Social Sciences., vol. 1 (33), p. 214-223, 2015.

[4] L.A. Tolstolesova, "Innovative strategy for the development of Russia in the face of increasing international competition, Novosibirsk", "SibAK", 2013.

[5] E.A. Kuzmin, "Problems of separate economic security in free trade: a look at the interaction of Russia and the WTO", Journal of the SRSTU (NPI). Series Socio-economic sciences, vol. 6, p. 44-59, 2012.

[6] V.G. Meloyan, A.I. Shevchenko, "Efficiency of the university in the international information and educational space", Bulletin of the Ministry of Internal Affairs of Russia, vol. 2 (36), P. 245-247, 2017.

[7] E.B. Kuznetsov, "National report on innovations in Russia 2016" [Electronic resource], Access to https://www.rvc.ru/upload/RVK_innovation_2016_v.pdf
[8] D.O. Yampolskaya, "Modern problems of innovation products commercialization", Science and practice integration as a mechanism of modern society development, pp. 176-179, august 2014 (XII international scientific conference, p. 524, july 2014)

[9] A.M.Zobov, E.A. Degtereva, V.U. Chernova, "Scientific-Industrial and Economic Cooperation Between Russia and BRICS States: Proposal of Effective Forms and Mechanism", Journal of Comparative Asian Development, vol. 15 (3), p. 333-360, 2016.

[10] T.G. Ozernikova, "Factors of Russia's integration into the world educational space", Journal Ural State University of Economics and Management, vol. 2 (58), P.92-100, 2015.

[11] Official site of the Federal Service of State Statistics of Russia. [Electronic resource], Access to: https://www.gks.ru/

[12] A.B. Temirbekova, A.T. Uskelenova, Sh.A. Boluspaev, N.A. Aldabergenov, "Influence of integration on the competitiveness of the national economy (the case of the EAE APC)", Eurasian Economic Integration, vol. 1 (26), P. 95-118, 2015.

[13] G.M. Fedorov, "Prospects for network cooperation between Russia and the EU countries in the innovation sphere in the Baltic", Balti. reg., vol. 1, P. 7-26, 2013.

[14] N.V. Chigirinskaya, "The creation of a unified regional educational system as a response to the challenges of globalization”, Jornal VolgGTU, vol. 4 (131), P.129-135, 2014

[15] A.A. Porokhovsky, "The economic system of modern Russia: the ways and objectives of development (monograph)", Moscow, Moscow State University, 2015.

[16] Ch. Enqing, "Problems of international integration in higher education on the example of cooperation between universities of China and Russia", Journal IGLU, vol 4 (21), P. 142-145, 2012.

[17] 2016 Global R \& D Funding Forecast, [Electronic resource], Access to: https://www.iriweb.org/sites/default/files/2016GlobalR\%26DFundingFo recast_2.pdf

[18] Doing Business [Electronic resource], Access to: http://www.doingbusiness.org/

[19] Global Competitiveness Index [Electronic resource], Access to: http://reports.weforum.org/global-competitiveness-index-2016-2017/

[20] Global Innovation Index [Electronic resource], Access to: https://www.globalinnovationindex.org/

[21] V.E. Guseva, E.A. Kuzmin, "Survival Rate and Lifecycle in Terms of Uncertainty: Review of Companies from Russia and Eastern Europe", Journal of Advanced Research in Law and Economics, vol. 7 (21), P. 1754-1766, 2016.

[22] E.A. Kuzmin, "Data on the empirically estimated corporate survival rate in Russia", Data in Brief, Vol. 16, P. 850-864, 2018.

[23] National accounts of OECD countries (2007-2015). [Electronic resource], Access to: http://www.oecd-ilibrary.org/economics/national-accounts-ofoecd-countries $2221433 \mathrm{x}$ 